\title{
Pharmacological Activities of Extracts and Isolated Phytochemical Constituents of Pandanus Odorifer (Forssk.) Kuntze
}

\author{
Saravanan VIVEKANANDARAJAH SATHASIVAMPILLAI ${ }^{1}$, Vinujan SHANMUGALINGAM ${ }^{2}$, \\ Pholtan RAJEEV SEBASTIAN RAJAMANOHARAN ${ }^{3}$
}

\begin{abstract}
Pandanus odorifer (Forssk.) Kuntze belongs to the Pandanaceae family. P. odorifer is used in traditional medicines to treat diabetes, jaundice, skin diseases, brain disorders, and urinary tract illnesses. This work aims to present a comprehensive review to analyze, summarize, and document the reported pharmacological activities of this plant species. Compounds such as eugenol, capric acid, germacrene B, camphor, and linalool have been discovered in this plant species. The major electronic databases (Web of Science, PubMed, ScienceDirect, and Scopus) were applied to identify the relevant published studies from 1900 to June 2021. In vitro and in vivo level of scientific evidence of pharmacological activities of various extracts and active compounds of this plant species is available at the moment. Pharmacological investigations show that P. odorifer possesses such as antioxidant, chemoprotective, antidepressant, antidiabetic, anti-inflammatory, and hepatoprotective activities. This work provides a basis for further pharmacological and phytochemical researches using P. odorifer.
\end{abstract}

Keywords: Pandanaceae, Pandanus odorifer, Pharmacological activities, Siddha Medicine, Sri Lanka

\footnotetext{
${ }^{1}$ Saravanan VIVEKANANDARAJAH SATHASIVAMPILLAI, KnowledgeLink Group, Inc., Waltham, MA 02451, USA, Poigai Institute, Batticaloa 30000, Sri Lanka, vivekanandarajahs@yahoo.co.uk, ORCID: 0000-0002-5938-0509

${ }^{2}$ Vinujan SHANMUGALINGAM, Palmyrah Research Institute, Palmyrah Development Board, Jaffna 40000, Sri Lanka, vinujans1989@gmail.com, ORCID: 0000-0002-9208-4090

${ }^{3}$ Pholtan RAJEEV SEBASTIAN RAJAMANOHARAN, Provincial Herbal Garden Management Center, Trincomalee 31000, Sri Lanka, Planning Unit, Provincial Department of Indigenous Medicine, Trincomalee 31000, Sri Lanka, drsrprajeev@ gmail.com, ORCID: 0000-0001$9341-5843$

İletişim / Corresponding Author: Saravanan VIVEKANANDARAJAH SATHASIVAMPILLAI e-posta/e-mail:

vivekanandarajahs@yahoo.co.uk

Geliș Tarihi / Received: 05.06.2021 Kabul Tarihi/Accepted: 13.08 .2021
} 


\section{INTRODUCTION}

Pandanus odorifer (Forssk.) Kuntze [synonym: Pandanus odoratissimus L.f.] is a small tree that belongs to the Pandanaceae family. It is called (Thaalai) in Tamil. This plant species usually grows on sandy coasts and it is distributed in Sri Lanka, India, China, Myanmar, Cambodia, Thailand, Vietnam, Malaysia, Laos, Philippines, and Indonesia. ${ }^{1,2}$

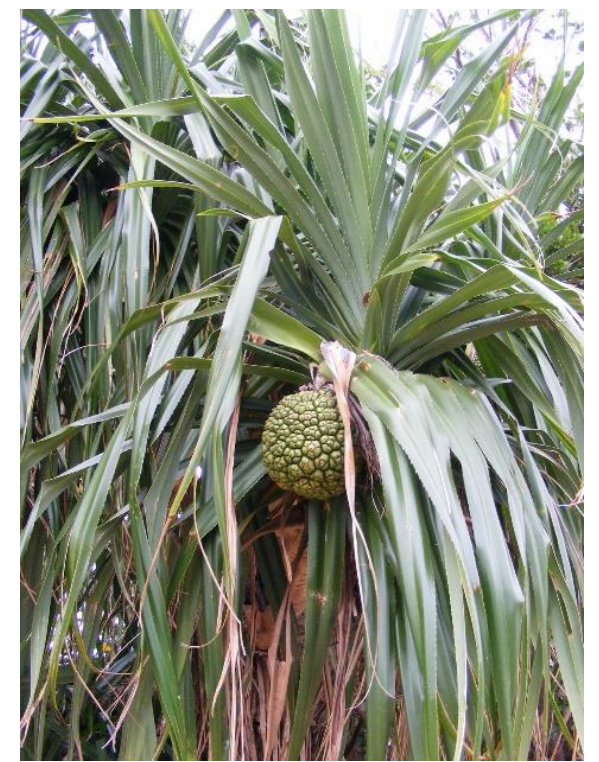

Figure 1. A Pandanus odorifer (Forssk.) Kuntze tree (Source: Kew Science, 2021)
$P$. odorifer is used to prepare food, medicine, essential oil, fragrance, ornaments, and weaving materials. ${ }^{1-3}$ Its leaves and fruits are used to flavor the foods. ${ }^{1,4}$

$P$. odorifer is used to treat various diseases in traditional medicines like Siddha Medicine and Ayurveda in Sri Lanka, Taiwan, and India. The traditional medicinal uses including part used, disorder treated, traditional medicine, country, and reference are presented in Table 1. Flower of this plant species is used to treat diseases such as diabetes, skin diseases, asthma, urinary tract illnesses, and syphilis in Siddha Medicine and Ayurveda in Sri Lanka and India. ${ }^{5-14}$ Whereas its leaf is utilized to treat including heart diseases, leprosy, tumor, brain diseases, and smallpox in Ayurveda in India. ${ }^{9,14}$ Furthermore, $P$. odorifer root is used to treat constipation, urinary tract illnesses, diabetes, fever, and thyroid disorders in Ayurveda in India. ${ }^{5,7}$ The flower has more traditional medicinal uses than the other parts like root, tender leaf, and leaf.

Table 1. Traditional Medicinal Uses of $P$. odorifer

\begin{tabular}{llllr}
\hline $\begin{array}{l}\text { Part } \\
\text { used }\end{array}$ & Disorder treated & $\begin{array}{l}\text { Traditional } \\
\text { medicine }\end{array}$ & Country & Reference \\
\hline Flower & $\begin{array}{l}\text { Syphilis, tumor, skin diseases, leukoderma, } \\
\text { leprosy, generating perspiration, earache, } \\
\text { bronchitis, blood diseases, asthma, urinary tract } \\
\text { illnesses, headache, rheumatism, constipation, } \\
\text { diabetes }\end{array}$ & $\begin{array}{l}\text { Siddha Medicine, } \\
\text { Ayurveda }\end{array}$ & $\begin{array}{l}\text { Sri Lanka, } \\
\text { India }\end{array}$ & $5-14$ \\
& $\begin{array}{l}\text { Brain diseases, heart diseases, leukoderma, } \\
\text { scabies, skin diseases, smallpox, tumor, } \\
\text { leprosy, syphilis, headache, rheumatism }\end{array}$ & Ayurveda & Sri Lanka, & India \\
& Backache & & & \\
& NS & Ayurveda & India & \\
\hline Root & $\begin{array}{l}\text { Constipation, urinary tract illnesses, diabetes, } \\
\text { syphilis, fever, thyroid disorders }\end{array}$ & Ayurveda & India, \\
Taiwan
\end{tabular}

Abbreviations NS: Not stated.

Several natural compounds have been identified in flower and root parts of $P$. odorifer. Compounds such as eugenol, capric acid, germacrene $\mathrm{B}$, camphor, dodecane, geranial, and linalool have been discovered in the flowers. ${ }^{9,18}$ Moreover, compounds including pinoresinol, kobusin, eudesmin, epipinoresinol, and vanillin have been found in the roots of this plant species. ${ }^{17}$ On the other hand, vanillin has been identified in both flowers and roots of $P$. odorifer. ${ }^{9,17,18}$ So far, only two parts of this plant species have been 
investigated to identify the compounds present in them. Anyhow, leaves, flowers, and root are used in traditional medicine to treat various illnesses (see Table 1). Thus, it is recommended that to study the chemistry of various extracts of these parts to identify the compounds which might be novel and might have several pharmacological activities. ${ }^{19}$

As stated above, $P$. odorifer is used to cure several ailments in traditional medicines.
However, there are only a few scientific pieces of evidence currently available for its traditional medicinal uses. So far, there is no comprehensive review available to analyze, summarize, and document the reported pharmacological activities of this plant species. Therefore, the aim of this work to present a comprehensive review to provide a basis to conduct more phytochemical and pharmacological investigations using $P$. odorifer in the future.

\section{MATERIALS AND METHODS}

The major electronic databases (Web of Science, PubMed, ScienceDirect, and Scopus) were applied to identify the relevant published studies of $P$. odorifer from 1900 to June 2021. "Pandanus odorifer" and
"Pandanus odoratissimus" were utilized as search terms in this work. Only researches related to pharmacological activities of this plant species were taken in account in this work.

\section{RESULTS AND DISCUSSION}

\section{Pharmacological Activities of $\boldsymbol{P}$. odorifer}

So far, in vitro and in vivo level of scientific evidence of pharmacological activities of various extracts and active compounds of this plant species is available. More information like level of scientific evidence, pharmacological activity, part used, extract/compound, bioassay/model, dose/concentration, duration, and reference are presented in Table 2. Pharmacological investigations show that $P$. odorifer possesses activities such as the antioxidant, chemoprotective, antidepressant, antidiabetic, anti-inflammatory, and hepatoprotective. ${ }^{17,20-}$ 26 More studies have been carried out to investigate the antioxidant activity of this plant species and the majority of studies have been conducted in in vivo models. Also, methanol extract is explored in more pharmacological activities such as antioxidant, antidepressant, antiinflammatory, and hepatoprotective activities. To date, plant parts namely root, flower, and leaf have exhibited various pharmacological activities. Remarkably, all these parts are used to treat various disorders in traditional medicines too. Hence, all the parts used in traditional medicines have demonstrated a pharmacological activity. Traditional medicinal uses including rheumatism, diabetes, brain diseases, and jaundice have been validated by revealing by reported antidiabetic, anti-inflammatory, antidepressant, and hepatoprotective activities. ${ }^{21,23-26}$ Still, there is no scientific evidence available for treating such as skin diseases, urinary tract illnesses, asthma, and tumors in traditional medicines. Hence, it is worth studying these pharmacological activities for creating more scientific evidence for the traditional medicinal uses. Only reported pharmacological activities which have the highest level of scientific evidence at the moment and used the lowest dose or concentration are discussed below.

\section{In Vivo Pharmacological Activities}

\section{Antidepressant Activity}

Raju et al. (2011) investigated the antidepressant potential of methanol leaf extract, and the extract at the concentration of $50 \mathrm{mg} / \mathrm{kg}$ was administered to mice for 30 minutes period. The results revealed that the extract has exhibited potential antidepressant activity. ${ }^{23}$ 


\section{Antidiabetic Activity}

An ethanolic extract from the root was orally administered to an alloxan-induced diabetic rat at the concentration of $150 \mathrm{mg} / \mathrm{kg}$ to investigate antidiabetic activity for ten days continuously and the extract unveiled a significant reduction in blood glucose levels. ${ }^{21}$

\section{Antiinflammatory Activity}

An extract prepared using methanol was applied on Carrageenan-induced acute paw edema in rat for three hours. The extract (100 $\mathrm{mg} / \mathrm{kg}$ ) inhibited the inflammation and the authors have not mentioned the part used to prepare the extract. ${ }^{24}$

\section{Hepatoprotective Activity}

El-Shaibany et al. (2016) studied the hepatoprotective potential of flower extract prepared using methanol. The extract at the concentration of $500 \mathrm{mg} / \mathrm{kg}$ was administered to an acetaminophen-induced hepatotoxic guinea pig for ten days. The results revealed that the extract unveiled a significant hepatoprotective activity at the stated dose. ${ }^{25}$

\section{In Vitro Pharmacological Activities}

\section{Antioxidant Activity}

An extract of root prepared using ethanol was investigated to study the antioxidant activity using lipid peroxidation inhibitory potential assay. The extract exhibited a significant antioxidant effect at $\mathrm{IC}_{50}$ of 8 $\mu \mathrm{g} / \mathrm{ml}^{21}$

\section{Chemoprotective Activity}

Kaewklom and Vejaratpimol (2011) investigated the chemoprotective activity of flower extract $(0.015 \mathrm{mg} / \mathrm{ml})$ using human keratinocyte stem cell lines. The authors discovered that the extract has a significant chemoprotective activity against stem cell lines. In this study, the authors did not state the solvent used to prepare the extract. ${ }^{22}$

\section{Toxicity Studies}

There are a few toxicity investigations have been carried out for the safety and efficacy purposes of $P$. odorifer extracts. More details such as part used, extract, model, dose, duration, and reference are listed in Table 3.
Root ethanol extract $(3000 \mathrm{mg} / \mathrm{kg}$ ) was orally administered to rats for 7 days showed no adverse effects or mortality. ${ }^{26}$ Furthermore, another study carried out by Raju et al. (2011) states that leaf methanol extract $(2000 \mathrm{mg} / \mathrm{kg})$ orally administered to mice for 14 days is also safe and produced neither mortality nor adverse effects. ${ }^{23}$ Thus, further in vivo studies should be conducted to have more scientific evidence to provide more information for safety and efficacy purposes. 


\begin{tabular}{|c|c|c|c|c|c|c|c|}
\hline $\begin{array}{l}\text { GÜSBD 2021 } \\
\text { GUJHS 2021; }\end{array}$ & $\begin{array}{l}\text { (3): 574- 580 } \\
\text { (3): } 574-580\end{array}$ & Üniversitesi Sa & $\begin{array}{l}\text { k Bilimleri Dergisi } \\
\text { of Health Sciences }\end{array}$ & $\begin{array}{r}\text { Derleme Makalesi } \\
\text { Review Article }\end{array}$ & & & \\
\hline $\begin{array}{l}\text { Level of } \\
\text { evidence }\end{array}$ & Pharmacological activity & Part used & Extract / compound & Bioassay / model & $\begin{array}{l}\text { Dose / } \\
\text { concentration }\end{array}$ & Duration & Reference \\
\hline In vitro & Antioxidant & NS & Methanol & DPPH radical scavenging assay & NS & NA & 20 \\
\hline In vitro & Antioxidant & Root & Ethanol $(80 \%)$ & DPPH radical scavenging assay & $10 \mu \mathrm{g} / \mathrm{ml}\left(\mathrm{IC}_{50}\right)$ & NA & 21 \\
\hline In vitro & Antioxidant & Root & $\begin{array}{l}\text { 3,4-bis(4-hydroxy-3- } \\
\text { methoxybenzyl) } \\
\text { tetrahydrofuran }\end{array}$ & Ferric thiocyanate assay & NS & NA & 17 \\
\hline In vitro & Antioxidant & Root & Pinoresinol & Ferric thiocyanate assay & NS & NA & 17 \\
\hline In vitro & Antioxidant & NS & Methanol & Hydroxyl radical scavenging assay & NS & NA & 20 \\
\hline In vitro & Antioxidant & Root & Ethanol $(80 \%)$ & $\begin{array}{l}\text { Lipid peroxidation inhibitory } \\
\text { potential assay }\end{array}$ & $8 \mu \mathrm{g} / \mathrm{ml}\left(\mathrm{IC}_{50}\right)$ & NA & 21 \\
\hline In vitro & Antioxidant & NS & Methanol & Nitric oxide radical scavenging assay & NS & NA & 20 \\
\hline In vitro & Antioxidant & NS & Methanol & Superoxide radical scavenging assay & NS & NA & 20 \\
\hline In vitro & Chemoprotective & Flower & NS & Human keratinocyte stem cell & $0.015 \mathrm{mg} / \mathrm{ml}$ & NA & 20 \\
\hline In vivo & $\begin{array}{l}\text { Antidepressant (Motor } \\
\text { coordination) }\end{array}$ & Leaf & Methanol & Mouse & $50 \mathrm{mg} / \mathrm{kg}$ & $30 \mathrm{~min}$ & 23 \\
\hline In vivo & $\begin{array}{l}\text { Antidepressant (Sodium } \\
\text { pentobarbital induced sleeping } \\
\text { time) }\end{array}$ & Leaf & Methanol & Mouse & $50 \mathrm{mg} / \mathrm{kg}$ & $30 \mathrm{~min}$ & 23 \\
\hline In vivo & $\begin{array}{l}\text { Antidepressant (Spontaneous } \\
\text { motor activity) }\end{array}$ & Leaf & Methanol & Mouse & $50 \mathrm{mg} / \mathrm{kg}$ & $120 \mathrm{~min}$ & 23 \\
\hline In vivo & Antidiabetic & Root & Ethanol $(80 \%)$ & Alloxan-induced diabetic rat & $150 \mathrm{mg} / \mathrm{kg}$ & $10 \mathrm{~d}$ & 21 \\
\hline In vivo & Anti-inflammatory & NS & Methanol & $\begin{array}{l}\text { Carrageenan-induced acute paw edema } \\
\text { rat }\end{array}$ & $100 \mathrm{mg} / \mathrm{kg}$ & $3 \mathrm{~h}$ & 24 \\
\hline In vivo & Anti-inflammatory & NS & Methanol & Formalin-induced chronic paw edema rat & $100 \mathrm{mg} / \mathrm{kg}$ & $3 \mathrm{~h}$ & 24 \\
\hline In vivo & Hepatoprotective & Flower & Methanol (85\%) & $\begin{array}{l}\text { Acetaminophen-induced hepatotoxic } \\
\text { guinea pig }\end{array}$ & $500 \mathrm{mg} / \mathrm{kg}$ & $10 \mathrm{~d}$ & 25 \\
\hline In vivo & Hepatoprotective & Root & Ethanol & Paracetamol-induced hepatotoxic rat & $200 \mathrm{mg} / \mathrm{kg}$ & $7 \mathrm{~d}$ & 26 \\
\hline
\end{tabular}

Abbreviations: NS: Not Stated; NA: Not Applicable; $\mathrm{IC}_{50}$ : Half-maximal inhibitory concentration; DPPH: 2,2-diphenyl-1-picrylhydrazyl 
Table 3. Reported Toxicity Studies of P. Odorifer

\begin{tabular}{lllcrr}
\hline Part used & Extract & Model & Dose $(\mathrm{mg} / \mathrm{kg})$ & Duration & Reference \\
\hline Leaf & Methanol & Mouse & 2000 & $14 \mathrm{~d}$ & 23 \\
\hline Root & Ethanol $(80 \%)$ & Rat & 3000 & $4 \mathrm{~h}$ & 21 \\
\hline Root & Ethanol & Rat & 3000 & $7 \mathrm{~d}$ & 26
\end{tabular}

\section{CONCLUSION AND RECOMMENDATIONS}

This work evaluated, summarized, and documented the reported relevant pharmacological and phytochemical studies of $P$. odorifer. Several compounds have been discovered in $P$. odorifer fruit and root. Also, antioxidant compounds have been isolated from roots. $P$. odorifer has several traditional medicinal uses. However, there are only a few scientific pieces of evidence available for these claims. Therefore, it is advised that to conduct more in vitro, in vivo, and clinical pharmacological and phytochemical investigations for various parts of this plant species. This work provides a basis for further pharmacological and phytochemical researches of $P$. odorifer.

\section{REFERENCES}

1. Bown, D. (1995). "Encyclopedia of Herbs and Their Uses". Dorling Kindersley.

2. Gamble, J.S. (1881). "A Manual of Indian Timbers: An Account of the Growth, Distribution, and Uses of the Trees and Shrubs of India and Ceylon, with Descriptions of Their Wood-structure". S. Low, Marston \& Company Limited.

3. Watt, S.G. (1908). The Commercial Products of India: Being an Abridgement of The Dictionary of the Economic Products of India. London.

4. Low, T. (1991). Wild Food Plants of Australia. Angus \& Robertson

5. Ilanchezhian, R. and Joseph, R. (2006). "Hepatoprotective and hepatocurative activity of the traditional medicine ketaki (Pandanus odoratissimus Roxb.)". Asian Journal of Traditional Medicines, 5, 212-218.

6. Jain, S.K. (1991). Dictionary of Indian folk medicine and ethnobotany. Deep publications.

7. Khare, C.P. (2011). Indian Herbal Remedies: Rational Western Therapy, Ayurvedic and Other Traditional Usage, Botany. Springer-Verlag Berlin Heidelberg.

8. Kirtikar, K.R. and Basu, B.D. (1935). Indian Medicinal Plants, Vol. II. Allahabad: Lalit Mohan Publication.

9. Raina, V.K, Kumar, A, Srivastava, S.K, Syamsundar, K.V. and Kahol, A.P. (2004). "Essential oil composition of 'kewda'(Pandanus odoratissimus) from India”. Flavour and Fragrance Journal, 19, 434-436.

10. Sathasivampillai, S.V, Rajamanoharan, P.R.S, Heinrich, M. and Munday, M. (2015). "Preparations and plants used to treat diabetes in Sri Lankan Siddha Medicine". Presented at the 3rd International Conference on Ayurveda, Unani, Siddha and Traditional Medicine, Institute of Indigenous Medicine, University of Colombo, Colombo, 67 .

11. Sathasivampillai, S.V, Rajamanoharan, P.R.S, Munday, M. and Heinrich, M. (2016). "Plants used to treat diabetes in Sri Lankan Siddha Medicine - An ethnopharmacological review of historical and modern sources". Journal of Ethnopharmacology, 198, 531-599. https://doi.org/10.1016/j.jep.2016.07.053.

12. Sathasivampillai, S.V, Rajamanoharan, P.R.S, Munday, M. and Heinrich, M. (2017). "Plants currently used to treat diabetes in Sri Lankan Siddha Medicine - an ethnobotanical survey in the Eastern Province". Presented at the World Congress Integrative Medicine \& Health 2017: part three, Springer Nature, Berlin, Germany, 333. https://doi.org/10.1186/s12906-017-1784-2.

13. Sathasivampillai, S.V, Rajamanoharan, P.R.S, Munday, M. and Heinrich, M. (2018). "Siddha medicine in eastern Sri Lanka today-continuity and change in the treatment of diabetes". Frontiers in Pharmacology, 9, 1022.

14. Warrier, P.K, Nambiar, V.P.K. and Ramankutty, C (1995). Indian Medicinal Plants Vol. 4. Orient BlackSwan.

15. Institute of Ayurveda and Alternative Medicine. (2021) Ayurvedic Plants of Sri Lanka.

http://www.instituteofayurveda.org/plants/plants_detail.p $\mathrm{hp} ? \mathrm{i}=970 \& \mathrm{~s}=$ Scientific name $\quad$ (Accessed 10.06.2021)

16. Nadkarni, K.M. (1996). Indian materia medica: with Ayurvedic, Unani-Tibbi, Siddha, Allopathic, Homeopathic, Naturopathic \& home remedies, appendices \& indexes. Bombay: Popular Prakashan Private Ltd.

17. Jong, T.T. and Chau, S.W. (1998). "Antioxidative activities of constituents isolated from Pandanus odoratissimus". Phytochemistry, 49, 2145-2148.

18. Nasim, N, Behera, J.K, Sandeep, I.S, RamaRao, V.V, Kar, B, Mishra, A, Nayak, S. and Mohanty, S. (2018). "Phytochemical analysis of flower from Pandanus odorifer (Forssk.) Kuntze for industrial application". Natural Product Research, 32, 2494-2497.

19. Li, K, Rollins, J. and Yan, E. (2018). "Web of Science use in published research and review papers 1997-2017: A 
selective, dynamic, cross-domain, content-based analysis". Scientometrics, 115, 1-20. https://doi.org/10. 1007/s11192-017-2622-5.

20. Londonkar, R. and Kamble, A. (2009). "Evaluation of free radical scavenging activity of Pandanus odoratissimus". International Journal of Pharmacology, $5,377-380$

21. Venkatesh, S, Kusuma, R, Sateesh, V, Madhava, R.B. and Mullangr, R. (2012). "Antidiabetic activity of Pandanus odoratissimus root extract". Indian Journal of Pharmaceutical Education and Research, 46, 340-345.

22. Kaewklom, S. and Vejaratpimol, R. (2011). "In vitro protective effect of Pandanus odoratissimus extract on ultraviolet B (UVB)-induced DNA damage". African Journal of Biotechnology, 10, 9165-9169.

23. Raju, S, Subbaiah, N.V, Reddy, K.S, Das, A. and Murugan, K.B. (2011). "Potential of Pandanus odoratissimus as a CNS depressant in Swiss albino mice". Brazilian Journal of Pharmaceutical Sciences, 47, 629-634.

24. Ramesh, L, Abhaykumar, K. and Reddy, V.C. (2010). "Anti-inflammatory activity of Pandanus odoratissimus extract". International Journal of Pharmacology, 6, 311314.

25. El-Shaibany, A, Molham, A.H, Al-Massarani, S, ElGamal, A, Al-Ajami, A. and Al-Adhl, A. (2016). "Hepatoprotective effect of Pandanus odoratissimus inflorescence extracts in acetaminophen-treated guinea pigs". Tropical Journal of Pharmaceutical Research, 15, 259-267.

26. Mishra, G, Khosa, R.L, Singh, P. and Jha, K.K. (2015). "Hepatoprotective potential of ethanolic extract of Pandanus odoratissimus root against paracetamolinduced hepatotoxicity in rats". Journal of Pharmacy \& Bioallied Sciences, 7, 45. 